Article

\title{
Assessment of Natural Radionuclide Distribution Pattern and Radiological Risk from Rocks in Precambrian Oban Massif, Southeastern Nigeria
}

\author{
Ekpenyong E. Ekpe ${ }^{1}$, Ubong C. Ben ${ }^{1}$, Stephen E. Ekwok ${ }^{1}$, Ebong D. Ebong ${ }^{1} \mathbb{D}$, Anthony E. Akpan ${ }^{1}$, \\ Ahmed M. Eldosouky ${ }^{2, *(\mathbb{D})}$, Kamal Abdelrahman ${ }^{3}$ (D) and David Gómez-Ortiz ${ }^{4}$ (D)
}

1 Applied Geophysics Unit, Department of Physics, University of Calabar, Calabar 540271, Nigeria; alexpencer1@gmail.com (E.E.E.); ubongben@unical.edu.ng (U.C.B.); styvnekwok@unical.edu.ng (S.E.E.); dickebong@yahoo.co.uk (E.D.E.); anthonyakpan@unical.edu.ng (A.E.A.)

2 Geology Department, Faculty of Science, Suez University, Suez 43518, Egypt

3 Department of Geology \& Geophysics, College of Science, King Saud University, Riyadh 11451, Saudi Arabia; khassanein@ksu.edu.sa

4 Department of Biology and Geology, Physics and Inorganic Chemistry, ESCET, Universidad Rey Juan Carlos, Móstoles, 28922 Madrid, Spain; david.gomez@urjc.es

* Correspondence: ahmed.eldosouky@sci.suezuni.edu.eg

\section{check for}

updates

Citation: E. Ekpe, E.; Ben, U.C.; Ekwok, S.E.; Ebong, E.D.; Akpan, A.E.; Eldosouky, A.M.; Abdelrahman, K.; Gómez-Ortiz, D. Assessment of Natural Radionuclide Distribution Pattern and Radiological Risk from Rocks in Precambrian Oban Massif, Southeastern Nigeria. Minerals 2022, 12, 312. https://doi.org/10.3390/ $\min 12030312$

Academic Editor: Jean-Michel Lafon

Received: 18 January 2022

Accepted: 25 February 2022

Published: 28 February 2022

Publisher's Note: MDPI stays neutral with regard to jurisdictional claims in published maps and institutional affiliations.

Copyright: (C) 2022 by the authors. Licensee MDPI, Basel, Switzerland. This article is an open access article distributed under the terms and conditions of the Creative Commons Attribution (CC BY) license (https:// creativecommons.org/licenses/by/ $4.0 /)$.

\begin{abstract}
A gamma spectrometric analysis of rock samples collected from the Precambrian Oban Massif, southeastern Nigeria, was performed to determine some primordial radioelements' activity concentrations: U-238, Th-232, and K-40, and their associated radiological hazards. The mean activity of the primordial radionuclides was determined to be $1073.06 \pm 0.65,160.74 \pm 1.32$, and $250.76 \pm 0.91 \mathrm{~Bq} \cdot \mathrm{kg}^{-1}$ for ${ }^{40} \mathrm{~K},{ }^{238} \mathrm{U}$, and ${ }^{232} \mathrm{Th}$, respectively, showing that they are inhomogeneously distributed, with activity changing with the rock type and location. The activity concentrations are highest in biotite garnet schist, quartz diorite, and biotite gneiss rock domains. The mean values of the radiological hazards are $0.08 \mathrm{~Bq} \cdot \mathrm{kg}^{-1}$ (alpha index), $2.15 \mathrm{~Bq} \cdot \mathrm{kg}^{-1}$ (gamma index), $2.06 \mathrm{~Bq} \cdot \mathrm{kg}^{-1}$ (internal) and $1.63 \mathrm{~Bq} \cdot \mathrm{kg}^{-1}$ (external4.30 Bq $\cdot \mathrm{kg}^{-1}$ (representative level index6), $602.23 \mathrm{~Bq} \cdot \mathrm{kg}^{-1}$, (radium equivalent), $780 \mathrm{nGy} \cdot \mathrm{h}^{-1}$ (total absorbed dose rate), $270.91 \mathrm{nGy} \cdot \mathrm{h}^{-1}$ (indoor), $509.78 \mathrm{nGy} \cdot \mathrm{h}^{-1}$ (outdoor), 624.99, 1329.07 and $1954.06 \mathrm{mSv} \cdot \mathrm{yr}^{-1}$ (outdoor, indoor and total annual effective dose equivalent, respectively), 6448.40 (cumulative excess lifetime cancer risk) and 248.94-3761.47 Bq $\cdot \mathrm{kg}^{-1}$ (annual gonadal dose equivalent). These results are higher than their various permissible limits (except at Ako Community) and suggest that rocks in the area may be unsuitable for constructing dwelling places. It is strongly advised that basic safety standards and precautionary measures recommended by the European Commission should be strictly adhered to while dealing with these rocks.
\end{abstract}

Keywords: NORM radionuclides; gamma spectrometry; radiological effect; excess lifetime cancer risk; Oban Massif; southeastern Nigeria

\section{Introduction}

Different types of rocks, which are usually mined, crushed into various aggregates, and used for the construction of assorted dwelling places and other civil engineering works, exist in high quantities in the different geological terrain of the world. Most of these materials, comprising sands, gravels, limestones, marls, slag, clays, and laterites, are used mainly to reinforce and strengthen composite materials [1]. These materials are also used to construct civil engineering structures such as septic drain fields, rail tracks, foundations, retaining walls, drains, road construction, and roadside edge drains in the construction industries. Their diverse uses for various engineering works have made them highly demanded, and as a result, extensively mined resources. The original deposits of 
some of these rocks have suffered massive overexploitation amid increasing demand. The resulting situation has caused miners to resort to crushing basement rocks to satisfy rising demands, particularly those of public service infrastructure-provisioning agencies.

Large quantities of Precambrian basement rocks occurring in various units in southeastern Nigeria are now being crushed into various aggregates and dimension stones, transported to other locations, and used for various purposes [2,3]. Elsewhere, the forest that used to cover the rocks is being deforested for commercial farming, thereby exposing workers to radiation from these rocks. In many such farms, these rocks are crushed for different purposes. It is expected that the commercial crushing activities will be extended to rocks in other areas in the future as deposits are running out in some locations. The main rock units comprise metasediments, amphibolites, granitic and migmatitic gneisses, schists, and phyllites. These rocks are intruded by pegmatites, granodiorites, granites, and olivine dolerites [4]. These rocks contain varying amounts of primordial radionuclides: uranium-238, thorium-232, and potassium-40 [5,6], whose concentrations vary with location, geology, and the physical and chemical processes responsible for their enrichment [7]. In crustal materials, potassium occurs naturally in different mineral forms, including sylvite $(\mathrm{KCl})$, carnallite $\left(\mathrm{KMgCl}_{3} \cdot 6\left(\mathrm{H}_{2} \mathrm{O}\right)\right)$, langbeinite $\left(\mathrm{K}_{2} \mathrm{Mg}_{2}\left(\mathrm{SO}_{4}\right)_{3}\right.$, polyhalite $\left(\mathrm{K}_{2} \mathrm{Ca}_{2} \mathrm{Mg}\left(\mathrm{SO}_{4}\right)_{4} \cdot 2\left(\mathrm{H}_{2} \mathrm{O}\right)\right.$, and the potassium feldspathic minerals (e.g., orthoclase). In contrast, thorium occurs as a trace element in phosphates, oxides, and silicates like monazite (Ce, $\mathrm{La}, \mathrm{Nd}, \mathrm{Th}) \mathrm{PO}_{4}$, thorianite $\left(\mathrm{ThO}_{2}\right)$, and thorite $\left(\mathrm{ThSiO}_{4}\right)$. Uranium is found in various accessory minerals, including brannerite $\left((\mathrm{U}, \mathrm{Ca}, \mathrm{Ce})(\mathrm{Ti}, \mathrm{Fe})_{2} \mathrm{O}_{6}\right)$, carnotite $\left(\mathrm{K}_{2}\left(\mathrm{UO}_{2}\right)_{2}\left(\mathrm{VO}_{4}\right)_{2} \cdot 2 \mathrm{H}_{2} \mathrm{O}\right)$, uranite $\left(\mathrm{H}_{4} \mathrm{O}_{2} \mathrm{U}\right)$, uraninite $\left(\mathrm{UO}_{2}\right)$, uranophane $\left(\mathrm{Ca}\left(\mathrm{UO}_{2}\right)_{2}\left(\mathrm{Si}_{2} \mathrm{O}_{3} \cdot 5 \mathrm{H}_{2} \mathrm{O}\right)\right.$, apatite $\left(\mathrm{Ca}_{5}\left(\mathrm{PO}_{4}\right)_{3}(\mathrm{OH}, \mathrm{F}, \mathrm{Cl})\right)$, sphene (or titanite, $\mathrm{CaTiOSiO} 5)$, pitchblende $\left(\mathrm{U}_{2} \mathrm{O}_{5} \cdot \mathrm{UO}_{3}\right)$ and zircon $\left(\mathrm{ZrSiO}_{4}\right)$ and so on [8]. Traces of some of these elements have been reported in rocks [9], soils [10,11], and water [12] in parts of the area. Therefore, exposure to ionizing radiation in the area is unavoidable due to the abundance of primordial radionuclides in the environment and even in some consumer products (e.g., tobacco, fuels, and building materials) [13,14].

Studies have shown that these lithophile elements are more concentrated in felsic rocks than their intermediate, mafic, and ultra-mafic counterparts $[6,11,15]$. When used as construction materials, radiation emitted by the lithophile elements in rock aggregates expose the population to indoor and outdoor radiation. The actual amount of radiation doses emitted by them depends on their mineralogical composition [16], but they exert potentially adverse impacts on the environment and public health [17]. Furthermore, economic and industrial activities such as the quarrying, leaching, handling, storage, and transportation of lithophile element-enriched materials, as well as artificial enrichment activities can enhance the effects of ionizing radiation on the environment. This ionizing radiation usually enters the human system through inhalation, injection, and ingestion $[18,19]$.

When these radiations enter the human system, small quantities accumulate in some sensitive parts of the body like the bone marrow, kidneys, female breast, and other sensitive organs through the bloodstream. The initial fractional quantities can accrue to levels that cause immediate or future harm to these sensitive organs with continuous exposure. Such harms can result in severe health challenges like bone, lung, pancreatic, and hematopoietic cancers $[20,21]$ and cell and kidney damages [22,23]. Furthermore, the population can also be exposed to naturally occurring radiation from mining operations through direct or indirect contact with the waste generated in operations and disposed of indiscriminately on farmlands and in water bodies [24] (see Figure 1). To the best of our knowledge, there has been no report of the spatial distribution and detailed investigation of the radionuclide constituents of the basement rocks in southeastern Nigeria and their probable effects on health. Therefore, it is pertinent to determine the environmental radiation levels to which the population is being exposed. Activity concentration observations will be used to estimate the potential radiological hazards that these radiations pose to inhabitants of residential buildings constructed from them. Therefore, this study, which is pioneering in outlook, aims to 
1. quantify the levels of radionuclides (U-238, Th-232, and K-40) in the basement rocks of Oban Massif;

2. map the spatial spread of radionuclides and determine the factors responsible for their enrichment;

3. determine the radiological hazards associated with these radionuclides;

4. contribute information and data to the global radionuclide database.

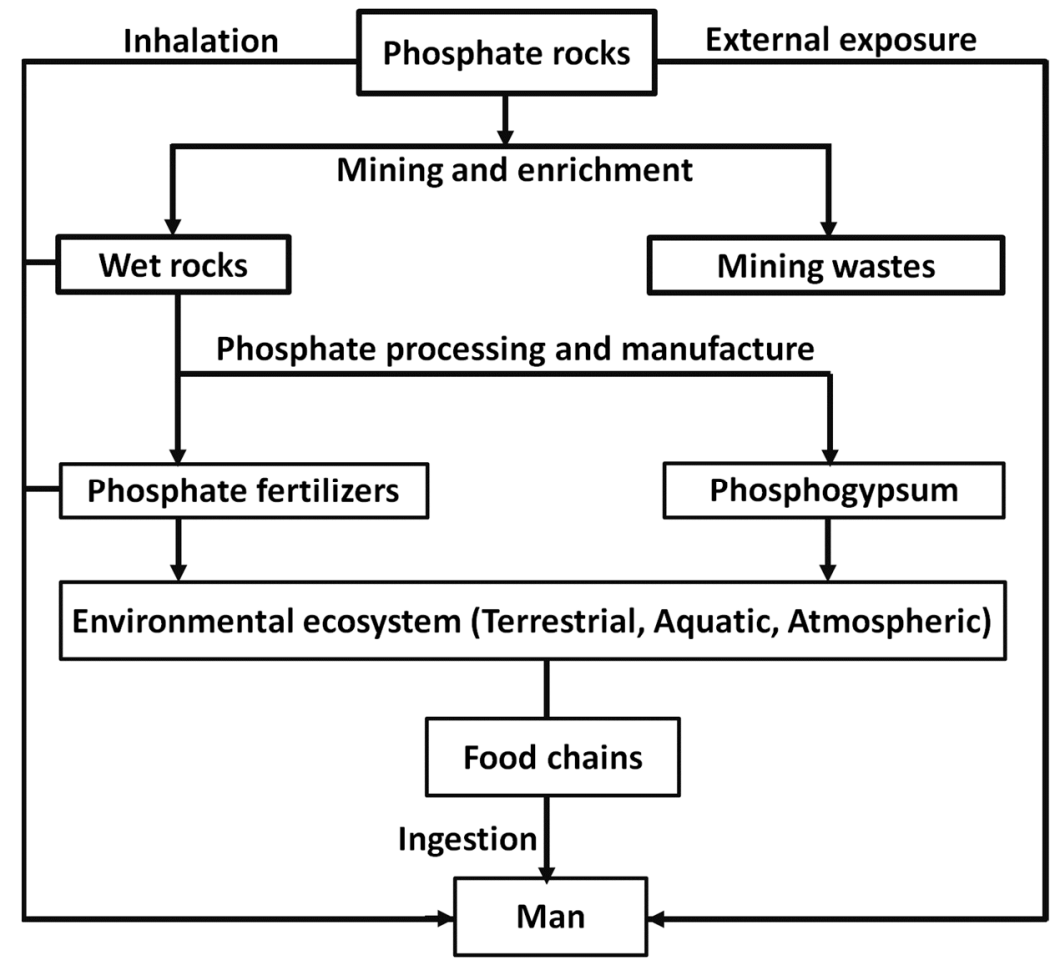

Figure 1. Environmental pathways of natural radionuclides from phosphatic rocks only (Modified from [25].

\section{Location, General Geology, and Tectonics of the Study Area}

The Oban Massif, a prominent feature in Nigeria's basement geology, is located between longitudes $8^{\circ} 02^{\prime}$ and $8^{\circ} 54^{\prime}$ E of the Greenwich Meridian and latitudes $5^{\circ} 00^{\prime}$ and $5^{\circ} 50^{\prime} \mathrm{N}$ of the Equator in southeastern Nigeria. It is bordered in the north and south by the Cretaceous Mamfe Embayment and Calabar Flank, respectively. It shares its eastern boundary with the Cameroun Mountains, while the Anambra basin borders it in the West. The massif covers an estimated area of about $10,000 \mathrm{~km}^{2}$ and is dominated by metamorphic rock units (migmatites, granites, banded gneisses, schists, phyllites, and amphibolites, Figure 2) of Precambrian age.

The rocks are intruded by diorites, granodiorites, pegmatites, monzonites, granites, and tonalities [26]. The granodiorites cover around $10 \%$ of the region and are the most noticeable intrusive rocks They are generally gigantic, weakly foliated, and medium-coarse grained $[4,26,27]$. Lateritic sediments that originate from the weathering of underlying rocks overlie the rocks in some locations. 


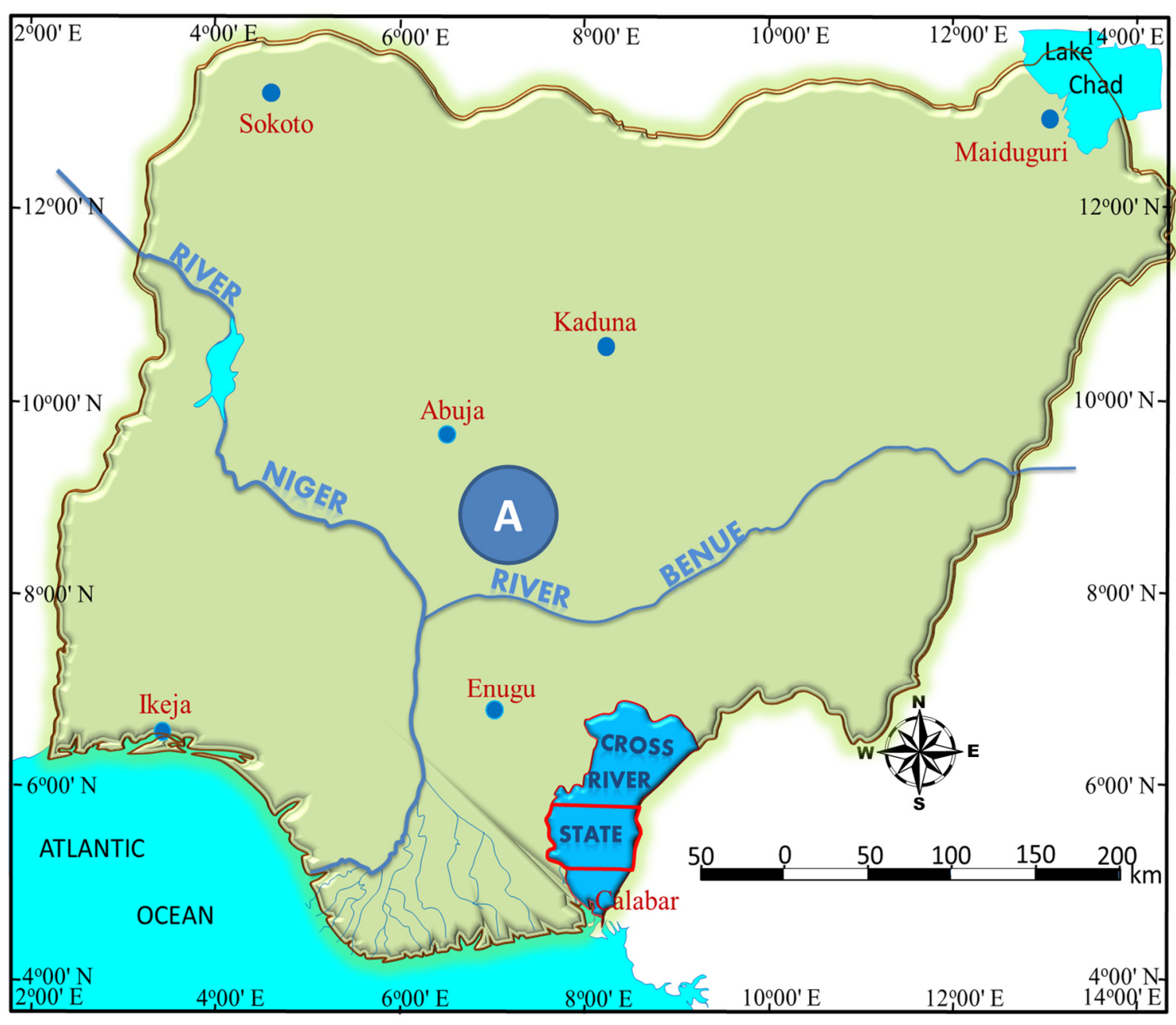

(A)

Figure 2. Cont. 


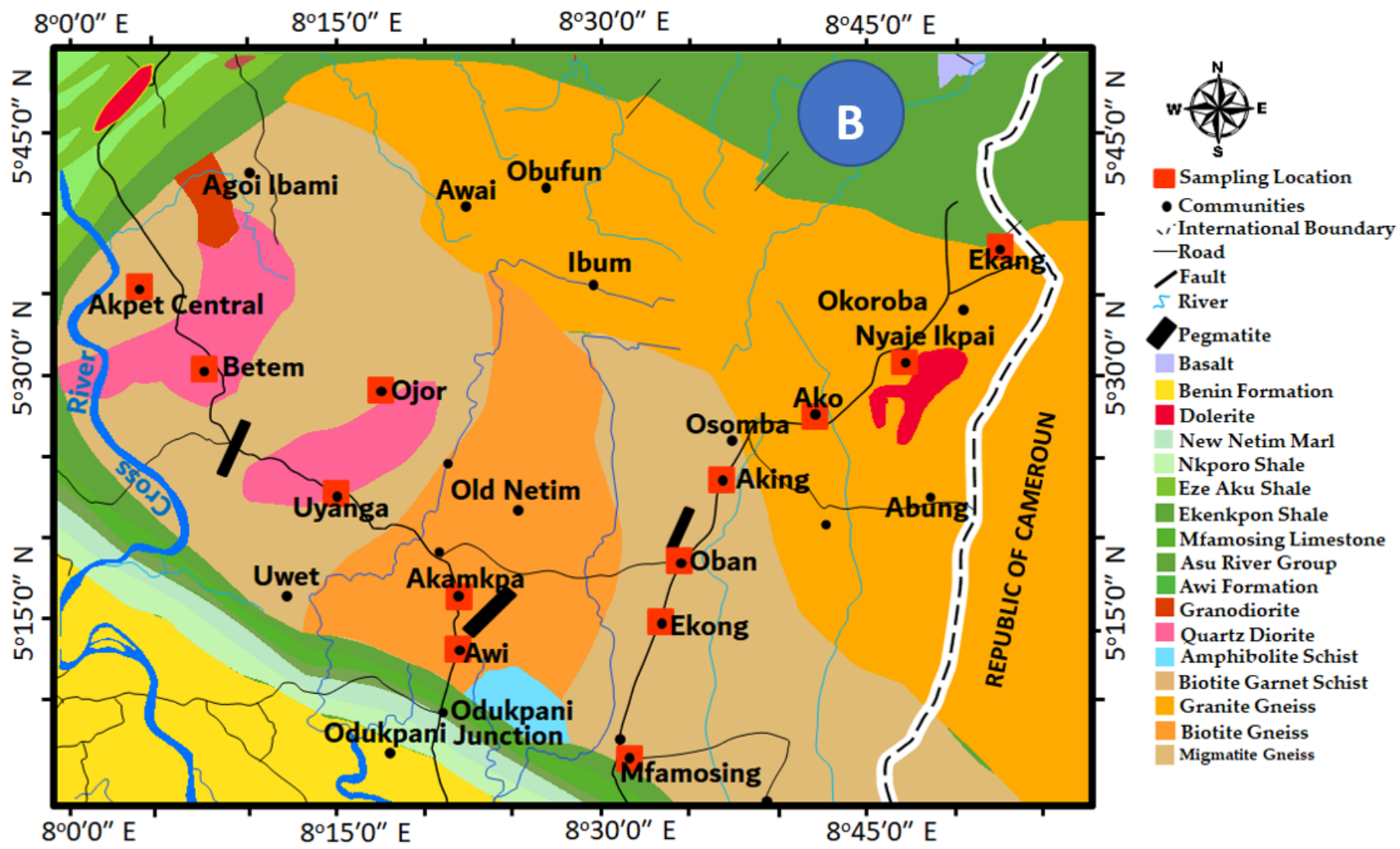

(B)

Figure 2. Map of Nigeria (A) showing the location of Cross River State. Insert (B) Generalized geological map of the study area using a cylindrical layer, made of lead to absorb X-rays generated when radiation made sudden contact with the detector. Before deploying the system for actual activity analysis, environmental radioactivity (background) counts were conducted by counting the activity of a sealed empty beaker put into the system for $12 \mathrm{~h}$. The results were used to correct the net gamma peaks observed from the different isotopes using Genie 2000 computer software. 


\section{Materials and Methods}

\subsection{Sample Collection}

Fifteen undisturbed rock samples collected from locations within the study area (Figure 2) were analyzed and used in this study. Field samplings were performed following EuroGeoSurveys guidelines [28] and Geochemical Mapping of Agricultural and Grazing Land Soils [29]. It involves collecting five samples at the center and corners of a pre-marked $100 \mathrm{~m} \times 100 \mathrm{~m}$ area of land located in each of the hard rock exposures in the study area. Some samples were collected in active quarries where the rocks are abundantly exposed. The generally thin overlaying materials were excavated to expose the fresh basement rocks that were eventually collected. Geographic coordinates of the sampling locations were measured using a handheld global positioning system. The samples were labeled using paper tapes and marker pens, packed in black polythene bags, and conveyed to the laboratory [7].

\subsubsection{Sample Preparation and Analyses}

The rock samples were sun-dried for a week, pulverized, split, homogenized, hermetically stored in polythene bags, and coded for easy identification and tracking. They were then sent to the National Institute for Radiation Protection and Research at the University of Ibadan, Nigeria, for analysis. The samples were oven-dried at a constant temperature of $110{ }^{\circ} \mathrm{C}$ for over $24 \mathrm{~h}$ to completely dehydrate them and, consequently, attain a constant dry weight. This was to reduce self-absorption and attain homogeneity [30]. The rock samples were carefully packed in a $39.1 \mathrm{~g}$ sealable, non-radioactive plastic container and labeled. The containers were tightly sealed and left for four weeks to allow ${ }^{226} \mathrm{Ra},{ }^{228} \mathrm{Ra}$, and their progenies to attain secular radioactive equilibrium [31]. Sealing of the samples also guarantees that radon gas does not leak when ${ }^{226} \mathrm{Ra}$ decays. The activity $\mathrm{A}_{\mathrm{c}}\left(\mathrm{Bq} \cdot \mathrm{kg}^{-1}\right)$, Equation (1), of each primordial radionuclide (U-235, Th-232 and K-40) was measured using a gamma ray spectrometer that uses a-3"x3" NAI(Th) scintillating detector connected to a multi-channel analyzer. Some of the specific properties of the NaI(Th) detecting system are full width, at half the maximum resolution of $1.33 \mathrm{MeV}{ }^{60} \mathrm{Co}$ at $60 \mathrm{keV}$, with a relative efficiency of the $1.33 \mathrm{MeV}{ }^{60} \mathrm{Co}$ at $7.5 \%$.

$$
\mathrm{A}_{\mathrm{c}}=\frac{\mathrm{N}_{\mathrm{net}}}{\mathrm{m} \cdot \varepsilon \cdot \mathrm{p}_{\gamma}}
$$

where $\mathrm{N}_{\text {net }}, \mathrm{m}, \mathrm{p}_{\gamma}$, and $\varepsilon$ are, respectively, the gamma rays' net count rates (sample count rate-background count rate) at energy $\mathrm{E}$, the mass of the sample $(\mathrm{kg})$, gamma ray yield (emission probability at a particular energy photopeak) and absolute efficiency of the detector. When gamma radiations emitted by the samples contact the detecting system, atoms in the NAI(Th) crystal become excited and, on de-excitation, a photon is ejected. The $63.3 \mathrm{keV}$ peak of ${ }^{234} \mathrm{Th}$ was used in calculating the activity concentration of ${ }^{238} \mathrm{U}$, and ${ }^{226} \mathrm{Ra}$ was computed using the average activity concentrations of ${ }^{214} \mathrm{~Pb}$ and ${ }^{214} \mathrm{Bi}$ of $295.3 \mathrm{keV}$ and $1764.5 \mathrm{keV}$, respectively. The mean concentrations of ${ }^{212} \mathrm{~Pb}(238.6 \mathrm{keV}), 228 \mathrm{Ac}$ $(911.1 \mathrm{keV})$, and ${ }^{208} \mathrm{Tl}(2614.7 \mathrm{keV})$, and that of ${ }^{40} \mathrm{~K}$, were used in determining the activity concentration of ${ }^{232} \mathrm{Th}(1460.0 \mathrm{keV})$. The $185.7 \mathrm{keV}$ gamma lines were used to calculate the activity concentration of ${ }^{235} \mathrm{U}$, which was adjusted by subtracting the contribution from the $186.2 \mathrm{keV}$ of ${ }^{226} \mathrm{Ra}$ [32]. According to [12,33], when secular equilibrium is established between parent and daughter nuclides, the activity of ${ }^{226} \mathrm{Ra}$ corresponds to that of ${ }^{238} \mathrm{U}$.

The detecting system was centrally positioned in a double-layered, fixed-bottom cylindrical chamber constructed from a $100 \mathrm{~mm}$-thick stainless-steel sheet. The chamber, which prevents background and other extraneous radiation from reaching the detector, is designed with a movable cover and a $0.3 \mathrm{~mm}$-thick inner concentric lead layer.

A fitting method was used in determining the full energy peak areas from the gamma ray energies. The procedure involved performing a broadband energy-based $(\approx 2000 \mathrm{keV})$ absolute efficiency, $\mathrm{E}_{\mathrm{ff}}$ calibration (equation 2 ) of the various radionuclides using standard 
sources $\left({ }^{137} \mathrm{Cs}(661.9 \mathrm{keV}),{ }^{133} \mathrm{Ba}(356.1 \mathrm{keV}),{ }^{60} \mathrm{Co}(1173.2\right.$ and $1332.5 \mathrm{keV})$, and ${ }^{226} \mathrm{Ra}$ $(1764.49 \mathrm{keV}))$ with known activities.

$$
E_{f f}=\frac{100 \cdot N_{p}}{I_{\gamma R} \cdot T O C \cdot A_{B O C}}
$$

where $\mathrm{N}_{\mathrm{p}}, \mathrm{I}_{\gamma \mathrm{R}}, \mathrm{TOC}, \mathrm{A}_{\mathrm{BOC}}$ are the net peak area at a particular gamma ray energy $\mathrm{E}_{\gamma}$, the intensity of the emitted gamma radiation, counting time and activity of the standard source (computed from Equation (3)) at the beginning of counting (BOC), respectively.

$$
\mathrm{A}_{\mathrm{BOC}}=\mathrm{A}_{\mathrm{DOC}} \cdot \mathrm{e}^{-\lambda(\mathrm{BOC}-\mathrm{DOC})}
$$

where $\lambda$ and $A_{D O C}$ are respectively the decay constant and activity of the standard source as at the date of calibration (DOC). Throughout the activity analysis period, daily monitoring of efficiency and energy calibration were routinely performed to ensure that high-quality data were acquired.

\subsubsection{Minimum Detectable Limit}

The minimum detectable limit (MDL) of the three naturally occurring radionuclides $\left({ }^{226} \mathrm{U},{ }^{232} \mathrm{Th}\right.$, and $\left.{ }^{40} \mathrm{~K}\right)$ was determined from Genie 2000 software using Equation (4) as

$$
\mathrm{MDL}=\frac{1.645 \sqrt{\mathrm{N}_{\mathrm{B}}}}{\mathrm{P}_{\gamma} \cdot \mathrm{n}(\mathrm{E}) \cdot \mathrm{T}_{\mathrm{c}} \cdot \mathrm{m}}
$$

where $\mathrm{N}_{\mathrm{B}}, \mathrm{n}(\mathrm{E})$, and $\mathrm{T}_{\mathrm{C}}$ are, respectively, the background counts, photopeak efficiency, counting time. 1.645 is a factor determined statistically at a $95 \%$ confidence level. The MDLs for the three radionuclides- ${ }^{226} \mathrm{U},{ }^{232} \mathrm{Th}$, and ${ }^{40} \mathrm{~K}$, were $0.12,0.11$, and $0.9 \mathrm{~Bq} \cdot \mathrm{kg}^{-1}$, respectively.

\subsubsection{Derivation of Uncertainty in Efficiency}

Since the absolute efficiency is a function of many variables, the overall uncertainty in the absolute efficiency, $\mathrm{u}\left(\mathrm{E}_{\mathrm{FF}}\right)$, is a combination of their contributing errors (Equation (5)). Thus, designating errors in $\mathrm{N}_{\mathrm{p}}, \mathrm{I}_{\gamma \mathrm{R}}, \mathrm{TOC}$, and $\mathrm{A}_{\mathrm{BOC}}$ as $\mathrm{u}(\mathrm{Np}), \mathrm{u}\left(\mathrm{I}_{\gamma \mathrm{R}}\right), \mathrm{u}(\mathrm{TOC})$, and $\mathrm{u}\left(\mathrm{A}_{\mathrm{BOC}}\right)$, then

$$
\mathrm{u}\left(\mathrm{E}_{\mathrm{ff}}\right)=\mathrm{E}_{\mathrm{ff}} * \sqrt{\left(\left[\frac{\mathrm{u}\left(\mathrm{N}_{\mathrm{p}}\right)}{\mathrm{N}_{\mathrm{p}}}\right]^{2}+\left[\frac{\mathrm{u}\left(\mathrm{I}_{\gamma \mathrm{R}}\right)}{\mathrm{I}_{\gamma \mathrm{R}}}\right]^{2}+\left[\frac{\mathrm{u}(\mathrm{TOC})}{\mathrm{TOC}}\right]^{2}+\left[\frac{\mathrm{u}\left(\mathrm{A}_{\mathrm{BOC}}\right)}{\mathrm{A}_{\mathrm{BOC}}}\right]^{2}\right)}
$$

The Genie 2000 software (Mirion Technologies, Atlanta, GA, USA) is programmed to neglect $\mathrm{u}(\mathrm{TOC})$ values whenever they become very small compared to the TOC values. Errors in $\mathrm{A}_{\mathrm{BOC}}$ were calculated from Equation (6) as.

$$
\mathrm{u}\left(\mathrm{A}_{\mathrm{BOC}}\right)=\mathrm{A}_{\mathrm{BOC}} * \sqrt{\left(\left[\frac{\mathrm{u}\left(\mathrm{A}_{\mathrm{DOC}}\right)}{\mathrm{A}_{\mathrm{DOC}}}\right]^{2}+(\mathrm{BOC}-\mathrm{DOC})^{2} \cdot \mathrm{u}^{2}(\lambda)\right)}
$$

The value of $u(N P)$ was obtained from the Genie 2000 software, while values of $\mathrm{u}(\lambda)$ and $\mathrm{u}\left(\mathrm{I}_{\gamma \mathrm{R}}\right)$ were extracted from the compilations of [34]. Equations (1)-(6) were automatically implemented in the Genie 2000 software that was used for the analysis

The activity concentrations of the various primordial radionuclides are shown in Table 1, while their basic statistics are shown in Figure 3. 

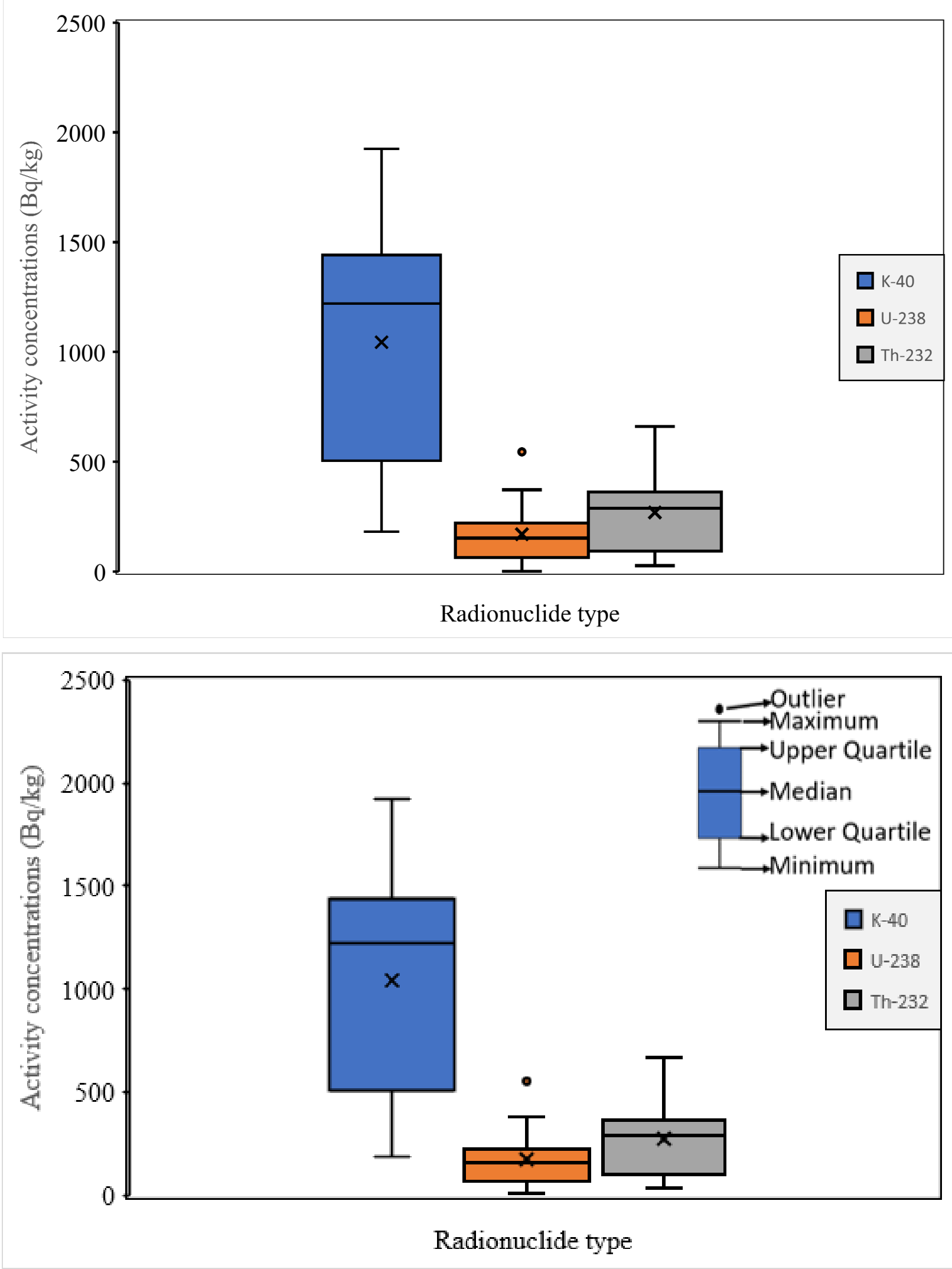

Figure 3. Basic statistics of the distribution of radionuclides in the rocks. 


\subsubsection{Assessment of Radiation Hazard Indices}

\section{Radium Equivalent}

The primordial radionuclides comprising ${ }^{226} \mathrm{Ra},{ }^{232} \mathrm{Th}$, and ${ }^{40} \mathrm{~K}$ are unequally distributed in terrestrial materials due to a lack of equilibrium between ${ }^{226} \mathrm{Ra}$ and its progenies. The concept of radium equivalent, $\mathrm{Ra}_{\mathrm{eq}}$, which is a weighted sum of activities from the naturally occurring radionuclides, was introduced for use in computing activities when $370 \mathrm{~Bq} \cdot \mathrm{kg}^{-1}$ of radium, $259 \mathrm{~Bq} \cdot \mathrm{kg}^{-1}$ of thorium, and $4810 \mathrm{~Bq} \cdot \mathrm{kg}^{-1}$ of potassium are synchronized to produce equal amounts of gamma radiation dose rates and by extension, radiation exposure [24,35]. $\mathrm{Ra}_{\mathrm{eq}}$ allows specific activity from various primordial radionuclides in terrestrial materials to be compared. According to the [36,37], for terrestrial materials to be considered safe for use in constructing places of habitation for humans, the $\mathrm{Ra}_{\text {eq }}$ (Equation (7)), must be less than $370 \mathrm{~Bq} \cdot \mathrm{kg}^{-1}$. The $\mathrm{Ra}_{\mathrm{eq}}$ observations are shown in Table 1.

$$
\operatorname{Ra}_{\mathrm{eq}}\left(\mathrm{Bq} \cdot \mathrm{kg}^{-1}\right)=\mathrm{A}_{\mathrm{Ra}}+1.43 \mathrm{~A}_{\mathrm{Th}}+0.077 \mathrm{~A}_{\mathrm{K}}
$$

\subsubsection{Alpha Index}

The alpha or internal index $\left(\mathrm{I}_{\alpha}\right)$ is a parameter used in quantifying the amount of excess $\alpha$-radiation to which occupants of buildings are exposed. The radiation is usually emitted by radon gas released from materials used in constructing dwelling places. For buildings to be safe for human occupation, the activity of ${ }^{226} \mathrm{Ra}$ must remain below $200 \mathrm{~Bq} \cdot \mathrm{kg}^{-1}$ upper limit [38]. The procedure adopted by [31], Equation (8), was used in computing $\mathrm{I}_{\alpha}$, as

$$
\mathrm{I}_{\alpha}=\frac{\mathrm{A}_{\mathrm{Ra}}}{200}
$$

where $A_{R a}$ is the activity of the alpha particle emitter $\left({ }^{226} \mathrm{Ra}\right.$ that is taken to represent the activity of ${ }^{238} \mathrm{U}$ when secular equilibrium is established) in the rocks. The recommended exemption and upper levels of Radium-226 activity concentration in building materials are 100 and $200 \mathrm{~Bq} \cdot \mathrm{kg}^{-1}$, respectively [39]. The distribution of $\mathrm{I}_{\alpha}$ in the rocks is shown in Table 1.

\subsubsection{Gamma Index}

The external index, sometimes called the gamma index, $\mathrm{I}_{\gamma}$, is a parameter introduced for selecting and categorizing building materials to reduce the excess gamma rays to which occupants of buildings constructed from them are exposed. The gamma indices of the various rock samples were evaluated using Equation (9) [31].

$$
\mathrm{I}_{\gamma}=\frac{\mathrm{A}_{\mathrm{Ra}}}{300}+\frac{\mathrm{A}_{\mathrm{Th}}}{200}+\frac{\mathrm{A}_{\mathrm{K}}}{3000}
$$

where $A_{T h}$ and $A_{K}$ are the activities of thorium and potassium, respectively. Equation (9) was used with the assumption that the radionuclides emit radiation at equal gamma dose rates with activities of 300,200 , and $3000 \mathrm{~Bq} \cdot \mathrm{kg}^{-1}$ for ${ }^{238} \mathrm{U},{ }^{232} \mathrm{Th}$, and ${ }^{40} \mathrm{~K}$, respectively [31].

\subsubsection{Internal Hazard Index}

Exposure of sensitive internal organs to ionizing radiations emitted by short-lived radionuclides such as radon in the decay series of uranium through ingestion and inhalation is hazardous to health. Consequently, the internal hazard index (Equation (10)) was developed to quantify hazards posed by $\alpha$-radiation to sensitive internal organs [31].

$$
\mathrm{H}_{\text {in }}=\frac{\mathrm{A}_{\mathrm{Ra}}}{185}+\frac{\mathrm{A}_{\mathrm{Th}}}{259}+\frac{\mathrm{A}_{\mathrm{K}}}{4810}
$$

where $\mathrm{H}_{\text {in }}$ is the internal hazard index $\left(\mathrm{Bq} \cdot \mathrm{kg}^{-1}\right)$. It is strongly recommended that $\mathrm{H}_{\text {in }}$ should not be more than unity in safe environments [24]. 


\subsubsection{External Hazard Index}

The external radiation hazard $\left(\mathrm{H}_{\mathrm{ex}}\right)$ is a single index widely used to evaluate the level of radiation that an individual is externally exposed to as he interacts with his physical environment. The index combines the various forms of gamma radiation emitted from primordial radionuclides in building materials (soils, rocks, and plants) to determine the indoor radiation dose delivered externally to an individual. The observed $\mathrm{H}_{\mathrm{ex}}$ values, computed using Equation (11) [35], are shown in Table 1.

$$
\mathrm{H}_{\mathrm{ex}}=\frac{\mathrm{A}_{\mathrm{Ra}}}{370}+\frac{\mathrm{A}_{\mathrm{Th}}}{259}+\frac{\mathrm{A}_{\mathrm{K}}}{4810}
$$

According to $[24,35]$, for materials to be considered safe, $H_{\text {ex }}$ values must not exceed unity.

\subsubsection{Representative Level Index}

The radioactivity level index, RLI (sometimes called representative level index), is a parameter usually used in estimating the level of radiation hazards emanating from a natural radionuclide in building materials. The RLI was computed from Equation (12).

$$
\mathrm{RLI}=\frac{\mathrm{A}_{\mathrm{Ra}}}{150}+\frac{\mathrm{A}_{\mathrm{Th}}}{100}+\frac{\mathrm{A}_{\mathrm{K}}}{1500}
$$

Building materials are considered safe for use in constructing dwelling places if their RLI values $\leq 1$ [35].

\subsubsection{Annual Gonadal Dose Equivalent}

The annual gonadal dose equivalent (AGDE) is a parameter that evaluates the degree of genetic implication of the annual gamma ray doses absorbed by the rapidly dividing cells existing in some sensitive organs in the body, such as the active bone marrow, lungs, female breast, gonads, and the bone surface. The AGDE values were estimated using Equation (13) [40].

$$
\operatorname{AGDE}\left(\mu \mathrm{Sv} \cdot \mathrm{yr}^{-1}\right)=3.09 \mathrm{~A}_{\mathrm{Ra}}+4.18 \mathrm{~A}_{\mathrm{Th}}+0.314 \mathrm{~A}_{\mathrm{K}}
$$

In [36], it is recommended that the world average limit of AGDE should be $300 \mu \mathrm{Sv} \cdot \mathrm{yr}^{-1}$.

\subsubsection{Absorbed Dose Rate}

The absorbed gamma dose rate, $\mathrm{D}_{\mathrm{R}}\left(\mathrm{nGy} \cdot \mathrm{h}^{-1}\right)$, usually measured at $1 \mathrm{~m}$ above the ground, is the quantity of energy absorbed by unit mass of matter per unit time from ionizing radiation emitted by primordial radionuclides [32]. The primordial radionuclides, ${ }^{238} \mathrm{U},{ }^{232} \mathrm{Th}$, and ${ }^{40} \mathrm{~K}$, are the main sources of ionizing radiation in the air. Dose rate observations for indoor $\left(D_{\text {Rindoor }}\right)$, outdoor $\left(D_{\text {Routdoor }}\right)$ air, and total $D_{R}$ were computed from Equations (14)-(16) with the assumption that there are no contributions from ${ }^{235} \mathrm{U}$ and its daughter products $\left({ }^{137} \mathrm{Cr}\right.$ and $\left.{ }^{90} \mathrm{Sr}\right)$.

$$
\begin{gathered}
\mathrm{D}_{\text {Rindoor }}\left(\mathrm{nGy} \cdot \mathrm{h}^{-1}\right)=0.92 \mathrm{~A}_{\mathrm{Ra}}+1.1 \mathrm{~A}_{\mathrm{Th}}+0.080 \mathrm{~A}_{\mathrm{K}} \\
\mathrm{D}_{\text {Routdoor }}\left(\mathrm{nGy} \cdot \mathrm{h}^{-1}\right)=0.462 \mathrm{~A}_{\mathrm{Ra}}+0.604 \mathrm{~A}_{\mathrm{Th}}+0.0417 \mathrm{~A}_{\mathrm{K}} \\
\mathrm{D}_{\mathrm{R}}=\mathrm{D}_{\text {Rindoor }}+\mathrm{D}_{\text {Routdoor }}
\end{gathered}
$$

where the constants represent factors used in converting the activities of ${ }^{238} \mathrm{U},{ }^{232} \mathrm{Th}$ and ${ }^{40} \mathrm{~K}$ $\left(\mathrm{Bq} \cdot \mathrm{kg}^{-1}\right)$ to their equivalent dose rates $\left(\mathrm{nGy} \cdot \mathrm{h}^{-1}\right)$ [36]. Observed $\mathrm{D}_{\mathrm{R}} \mathrm{s}$ values are shown in Table 1. 


\subsubsection{Annual Effective Dose Equivalent}

Studies have revealed that adults usually spend an average of $80 \%$ of their time indoors. They encounter ionizing radiation circulating in the air in their rooms emitted by radionuclides in building materials. They spend the rest of their time outdoors, where they encounter radiation circulating in the air outside their rooms. Using the recommendation of [36], the indoor and outdoor annual effective dose equivalents (AEDE ${ }_{\text {Indoor }}$ and $\mathrm{AEDE}_{\text {Outdoor }}$ ) were computed using Equations (17) and (18). If average outdoor and indoor occupancy factors are $20 \%$ and $80 \%$, respectively, the corresponding $\mathrm{AEDE}_{\text {outdoor }}$ and $\mathrm{AEDE}_{\text {indoor }}$ can be determined using a conversion coefficient of $0.7 \mathrm{~Sv} / \mathrm{Gy}$ for the absorbed dose in the air to annual effective doses as

$$
\begin{gathered}
\operatorname{AEDE}_{\text {Indoor }}\left(\mathrm{mSv} \cdot \mathrm{yr}^{-1}\right)=\mathrm{D}_{\text {Rindoor }}\left(\mathrm{nGy} \cdot \mathrm{h}^{-1}\right) \times 8760 \times 0.8 \times 0.7 \mathrm{~Sv} \cdot \mathrm{Gy}^{-1}=\mathrm{D}_{\text {Rindoor }}\left(\mathrm{nGy} \cdot \mathrm{h}^{-1}\right) \times 4.906 \mu \mathrm{Sv} \\
\mathrm{AEDE}_{\text {Outdoor }}\left(\mathrm{mSv} \cdot \mathrm{yr}^{-1}\right)=\mathrm{D}_{\text {Routdoor }}\left(\mathrm{nGy} \cdot \mathrm{h}^{-1}\right) \times 8760 \times 0.2 \times 0.7\left(\mathrm{~Sv} \cdot \mathrm{Gy}^{-1}\right)=\mathrm{D}_{\text {Rindoor }}\left(\mathrm{nGy} \cdot \mathrm{h}^{-1}\right) \times 1.226 \mu \mathrm{Sv}
\end{gathered}
$$

Observed values of the $\mathrm{AEDE}_{\text {Indoor }}$ and $\mathrm{AEDE}_{\text {Outdoor }}$ are shown in Table 1. The total annual effective dose, $\mathrm{AEDE}_{\text {total }}$ (Equation (19)) was determined by the sum of Equations (17) and (18).

$$
\mathrm{AEDE}_{\text {total }}\left(\mathrm{mSv} \cdot \mathrm{yr}^{-1}\right)=\mathrm{AEDE}_{\text {Indoor }}+\mathrm{AEDE}_{\text {Outdoor }}
$$
Table 1.

Observed values of the $\mathrm{AEDE}_{\text {total }}, \mathrm{AEDE}_{\text {Indoor }}$ and $\mathrm{AEDE}_{\text {Outdoor }}$ are tabulated in

\subsubsection{Excess Lifetime Cancer Risk (ELCR)}

ELCR expresses the risk of someone developing cancer after exposure to radiation emitted by naturally occurring radionuclide materials. Equation (20) was used in computing the ELCR value. Observed results are shown in Table 1.

$$
\mathrm{ELCR}=\mathrm{AEDE}_{\text {total }} \times \mathrm{LE} \times \mathrm{RF}
$$

where LE is life expectancy (66 years) and RF is the risk (or fatal cancer risk) factor; the International Commission for Radiological Protection fixed its value at 0.05 [41].

\section{Results and Discussion}

\subsection{Radionuclide Concentrations and Distributions Pattern}

The activity concentrations of the primordial radionuclides in the study area are presented in Table 1 . The activity concentrations of the primordial radionuclides vary from $182.22 \pm 0.08$ (Ekong Community) to $1924.29 \pm 134.63$ (Aking Community), with a mean of $1073.06 \pm 0.65 \mathrm{~Bq} \cdot \mathrm{kg}^{-1}$ for ${ }^{40} \mathrm{~K}, 22.01 \pm 0.38$ (observed at Ako Community) to $545.61 \pm 97.46$ (Mfamosing Community), with a mean of $160.74 \pm 1.32 \mathrm{~Bq} \cdot \mathrm{kg}^{-1}$ for ${ }^{238} \mathrm{U}$, and $27.13 \pm 0.20$ (Ako Community) to $661.51 \pm 65.78$ (Betem Community), with a mean of $250.96 \pm 0.91 \mathrm{~Bq} \cdot \mathrm{kg}^{-1}$ for ${ }^{232} \mathrm{Th}$. These results confirm that the radionuclides are unevenly distributed over the studied areas and even inside the same formations [42]. Studies have shown that the uneven distribution of radionuclides in rocks could result from both anthropogenic and natural events. However, since there are no significant anthropic radionuclide-enriching activities, such as geothermal energy generation, mineral extraction, mining, processing and milling, production of hydrocarbons (coal, oil and gas), recycling, and production of industrial minerals like barytes, clays, or phosphates [43] in these areas, the enrichments must be from natural causes. Thus, terrestrial materials in the area are dominated by high radionuclide-emitting rocks. Emissions from rocks in the area (except at 10 sites) are higher than the world averages of 33,45 , and $412 \mathrm{~Bq} \cdot \mathrm{kg}^{-1}$ for ${ }^{238} \mathrm{U},{ }^{232} \mathrm{Th}$, and ${ }^{40} \mathrm{~K}$, respectively [44].

The high abundance of ${ }^{40} \mathrm{~K}$ in the rocks conforms to geological expectations, as potassium is the eighth-most abundant element, with an estimated $1.84 \%$ profusion in crustal 
materials. The abundance of potassium in rocks made it a major constituent of several rock-forming minerals, especially the potash-rich k-feldspar and some heavy minerals [45]. The high activity of ${ }^{40} \mathrm{~K}$ in the Aking area was attributed to the abundance of feldsparenriched dolerite that intrudes into the granitic gneiss host rock [46]. The variations in activity concentration of natural radionuclide elements are presented in Table 1, and its summary statistics is shown in Figure 3.

The spatial distribution of the naturally occurring radionuclides and the processes responsible for their enrichment are unevenly distributed. The relationship between Th and $\mathrm{U}$ abundance, assessed using $\mathrm{U} / \mathrm{Th}$ ratios, varies between 0.07 and 4.37 (mean of 2.01).

This average value of $U / T h$ observations is higher than the 0.22 global average value in gneissic rocks [47]. In locations where U/Th ratios are higher than the world average value, the continental crust has experienced some form of tectono-thermal disturbance that has caused hypogene fluids to be ejected into the host [48]. The nearly perfect coincidence in locations with high Th/U ratios and locations of intrusive rocks (Figure 2), affirms this assertion. However, locations with low U/Th indicate that processes responsible for U-enrichment are higher than that of [44]. Furthermore, it is also possible that weathering and other soil-forming processes might have caused the depletion of $U$ from the rocks in some locations, leading to their uneven spatial distribution [49].

\subsection{Environmental Impacts of Radionuclides}

Alpha and gamma indices, radium equivalent, and representative level index.

The alpha index varies between 0.11 and $2.73 \mathrm{~Bq} \cdot \mathrm{kg}^{-1}$. The mean value of $0.80 \mathrm{~Bq} \cdot \mathrm{kg}^{-1}$ exceeds the exemption limit of $0.5 \mathrm{~Bq} \cdot \mathrm{kg}^{-1}$ proposed by [35]. Rocks emitting the highest amounts of radon gas seem to be more abundant in areas around Mfamosing $\left(2.73 \mathrm{~Bq} \cdot \mathrm{kg}^{-1}\right)$, Akamkpa $\left(1.86 \mathrm{~Bq} \cdot \mathrm{kg}^{-1}\right)$, Betem $\left(1.16 \mathrm{~Bq} \cdot \mathrm{kg}^{-1}\right)$, Uwet $\left(1.05 \mathrm{~Bq} \cdot \mathrm{kg}^{-1}\right)$, Uyanga $\left(0.84 \mathrm{~Bq} \cdot \mathrm{kg}^{-1}\right)$, Ekang $\left(0.82 \mathrm{~Bq} \cdot \mathrm{kg}^{-1}\right)$ and Awi $\left(0.76 \mathrm{~Bq} \cdot \mathrm{kg}^{-1}\right)$, and consequently, may not be very suitable for use in constructing dwelling places. However, since alpha radiation has low penetrating power and a low travelling range even in the air, the particles may not pose severe life challenges. Variations in the gamma index were observed to be between 0.35 to $4.38 \mathrm{~Bq} \cdot \mathrm{kg}^{-1}$ with a mean value of $2.15 \mathrm{~Bq} \cdot \mathrm{kg}^{-1}$ (Table 1). These observations indicate that rocks in the area emit several gamma radiation doses above the recommended emission limit of $1 \mathrm{~Bq} \cdot \mathrm{kg}^{-1}$ [50] (International Atomic Energy Agency, IAEA, 1996). Consequently, it may be unsafe for use in building dwelling places (except at Ako and Ekang Communities). Radium equivalent observations vary from 92.52 to $1246.38 \mathrm{~Bq} \cdot \mathrm{kg}^{-1}$ (mean of $602.23 \mathrm{~Bq} \cdot \mathrm{kg}^{-1}$ ). Excepting two locations (13.33\%), $\mathrm{Ra}_{\mathrm{eq}}$ observations are higher than the recommended limit $\left(370 \mathrm{~Bq} \cdot \mathrm{kg}^{-1}\right)$ set by [36].

The mean representative level index is $4.53 \mathrm{~Bq} \cdot \mathrm{kg}^{-1}$ (minimum of 0.56 and maximum of $8.76 \mathrm{~Bq} \cdot \mathrm{kg}^{-1}$ ). These results show that RLI observations, which are commonly used as tools for screening building materials from which emitted radiation may pose challenges to health [38], are higher than the $1 \mathrm{~Bq} \cdot \mathrm{kg}^{-1}$ permissible limit except at Ako Community, where it is lower $\left(0.56 \mathrm{~Bq} \cdot \mathrm{kg}^{-1}\right)$. 
Table 1. Activity concentration of the radionuclides and radiological parameters.

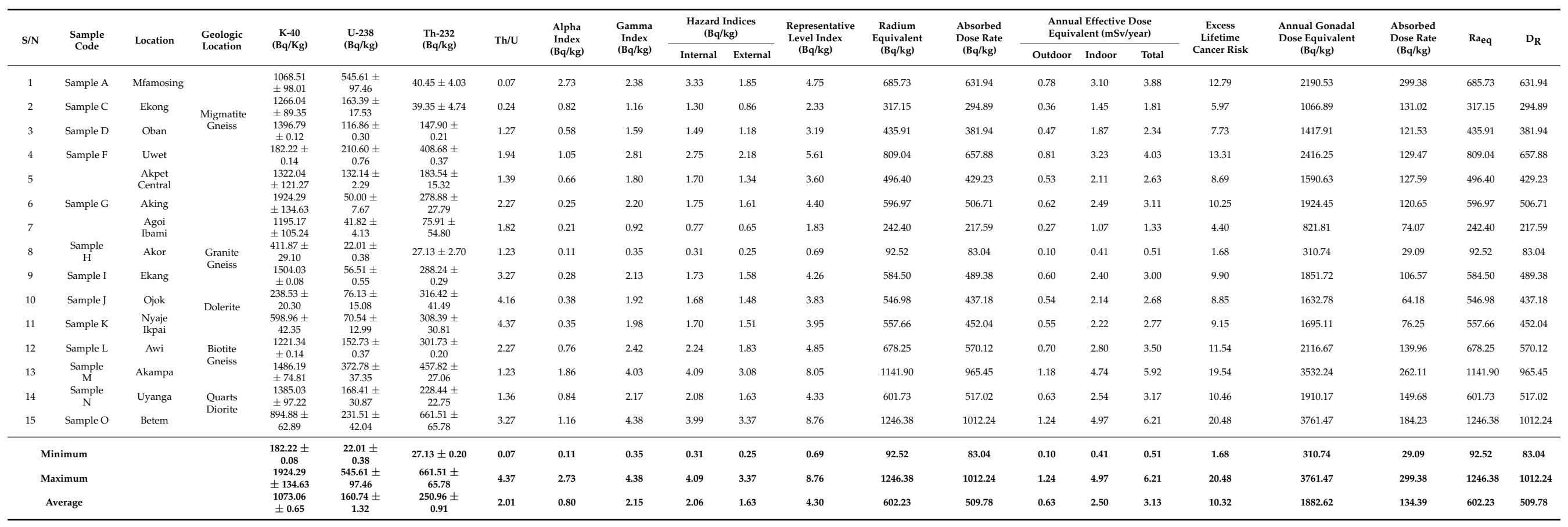




\subsection{Internal and External Hazard Indices}

The risk posed by radiation emitted from rocks to the internal and external organs vary between 0.31 and $4.09 \mathrm{~Bq} \cdot \mathrm{kg}^{-1}$ (mean of $2.06 \mathrm{~Bq} \cdot \mathrm{kg}^{-1}$ ), and 0.20 to $3.37 \mathrm{~Bq} \cdot \mathrm{kg}^{-1}$ (mean of $1.63 \mathrm{~Bq} \cdot \mathrm{kg}^{-1}$ ), respectively. These mean values are above the $1 \mathrm{~Bq} \cdot \mathrm{kg}^{-1}$ upper permissible limit recommended by [36] except at Ako and Ekong (for external hazard only. Therefore, these rocks may be ideally unsuitable for constructing dwelling places. In Ako and Ekong Communities, the rocks are ideally safe for building residential houses and other civil engineering structures. However, the rocks are radiologically unsafe in other locations due to the large doses of gamma radiation that they emit. These radiations become the main sources of radiation exposure to the internal and external organs. While external exposure occurs through direct contact with radionuclides and ionizing radiation emitted from them, internal exposure occurs through a variety of biological processes, including the inhalation of Rn-220, Rn-222 and their progenies; ingestion, and injection [24,51]. When the population is exposed to this radiation either inside their residential buildings or outside while interacting with other civil infrastructure, small amounts of this radiation accumulate in some sensitive parts of the body. In some cases, they can accumulate to levels where they start causing life-threatening challenges such as cancer to the exposed population $[20,22,23]$.

\subsection{Dose Rate, Absorbed Dose Rate, and Annual Effective Dose Equivalent}

The extent to which radiant particles damage sensitive tissues and organs depends on the amount of radiation they receive. The total dose rate of gamma radiation adsorption, Dr varies from 126.90 (Ako Community) to $34 \mathrm{nGyh}^{-1}$ (Mfamosing Community). It strongly correlates with the radium equivalent activity $\left(R^{2}=+0.995\right)$ (Figure 4$)$, showing its dependence on gamma emission from the rocks. The overall mean of $\operatorname{Dr}\left(509.78 \mathrm{nGy} \cdot \mathrm{h}^{-1}\right)$ is higher than the recommended upper limit of $84 \mathrm{nGy} \cdot \mathrm{h}^{-1}$.

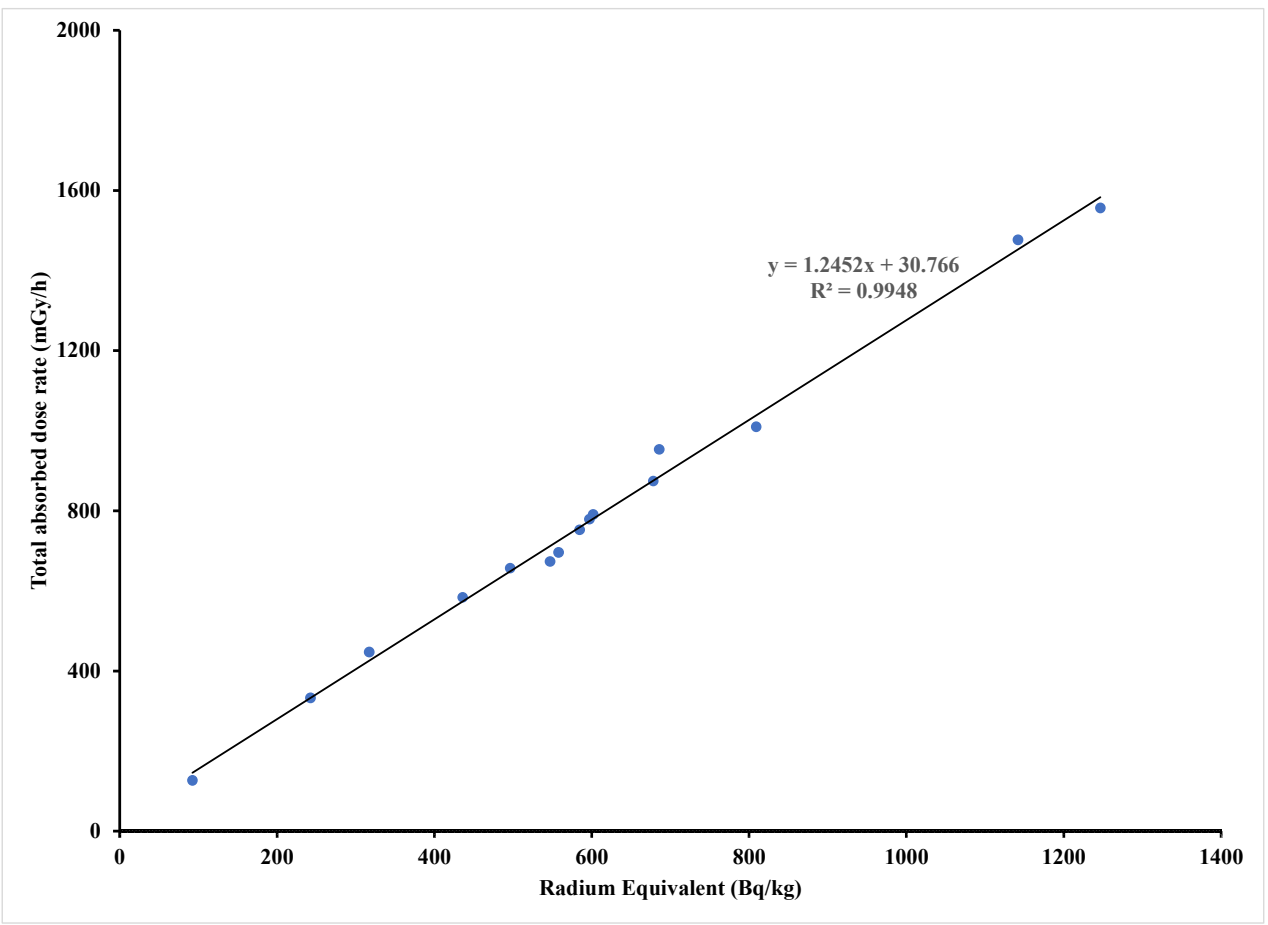

Figure 4. Correlation between absorbed dose rate and radium equivalent.

Since many adults spend a more significant part of their time indoors $(\approx 80 \%)$, indoor radiation originating mainly from building materials accounts for a greater portion of their radiation exposure than these buildings' outdoor counterparts [32]. The annual effective dose equivalent results show that when these rocks are used in constructing dwelling places, the inhabitants of such buildings will experience indoor gamma radiation dose 
rates of 215.15 to $2669.33 \mathrm{mSv} \cdot \mathrm{yr}^{-1}$ (average of $1329.07 \mathrm{mSv} \cdot \mathrm{yr}^{-1}$ ), outdoor rates of 101.81 to $1241.01 \mathrm{mSv} \cdot \mathrm{yr}^{-1}$ (average of $624.99 \mathrm{mSv} \cdot \mathrm{yr}^{-1}$ ), totaling 316.96 to $3910.34 \mathrm{mSv} \cdot \mathrm{yr}^{-1}$ (average of $1954.06 \mathrm{mSv} \cdot \mathrm{yr}^{-1}$ ) doses of gamma radiation. The average value of the total doses of radiation received in the area is higher than the recommended world average value of $0.49 \mathrm{mSv} \cdot \mathrm{yr}^{-1}$ [52].

\subsection{Annual Gonadal Dose Equivalent and Excess Lifetime Cancer Risk}

The impacts of radiation on some of the most sensitive organs in the body, such as the female breast, bone marrow, thyroid, lung, and gonads have attracted immense attention in actinobiology and even in other fields like health physics and epidemiology and radiology. This interest has risen because when these organs are exposed to ionizing radiation, fractional amounts of the incident radiation are gradually stored by them. They can accrue to levels where they become harmful and can even cause damage $[10,36]$. The AGDE parameter quantifies the total annual amount of radiation received by these organs from the activities of the primordial radionuclides.

The AGDE observations vary from 310.76 (Ako Community) to $3761.47 \mu \mathrm{Sv} \cdot \mathrm{yr}^{-1}$ (Betem Community), with an average of $1882.62 \mu \mathrm{Sv} \cdot \mathrm{yr}^{-1}$. This average value of AGDE is over six times higher than the recommended permissible limit of $300 \mu \mathrm{Sv} \cdot \mathrm{yr}^{-1}$ [53]. Nevertheless, the average AGDE is still less than observations from other regions. For example, [54] reported a $2398 \mu \mathrm{Sv} \cdot \mathrm{yr}^{-1}$ value from the Eastern Desert (Egypt). However, basic safety standards and precautionary measures recommended by [55] should be strictly adhered to while dealing with these rocks.

The ELCR evaluates the chances of an individual suffering from cancer in their lifetime due to exposure to ionizing radiation emitted either by radionuclides in materials used in constructing a dwelling place (indoor ELCR) or from those circulating outside (outdoor ELCR). The observed average total ELCR (6448.40) is higher than the $300 \mu \mathrm{Sv} \cdot \mathrm{yr}^{-1}$ upper limit recommended by [36] in building materials [56]. Results of the AGDE and ECLR reveal that the rocks constitute a high radiological risk to both quarry workers and residents of houses constructed using them [56]. However, as shown in Table 2, higher activity concentrations that translate to higher radiological parameters, including ELCR, have been reported in other locations.

Table 2. Comparison of mean activity concentrations in the present study with other results available in literature [51,57-66].

\begin{tabular}{|c|c|c|c|c|}
\hline Location & $\mathrm{U}-238(\mathrm{~Bq} / \mathrm{kg})$ & Th-232 (Bq/kg) & $\mathrm{K}-40$ (Bq/Kg) & Source \\
\hline Present study & 160.7 & 251.0 & 1073.1 & Present study \\
\hline Semnan Province, Iran & 77.0 & 45.0 & 1017.0 & [51] \\
\hline Uro (Sudan) & 4131.0 & 7.5 & 63.2 & [57] \\
\hline Florida (USA) & 1600.0 & 20.0 & BDL & [58] \\
\hline Arusha (Tanzania) & 5022.0 & 717.0 & 286.0 & [59] \\
\hline El-Mahamid (Egypt) & 567.0 & 217.3 & 238.5 & [59] \\
\hline Western El-Mashash & 666.0 & 329.4 & 329.4 & [59] \\
\hline Jordan & 1044.0 & 2.0 & 8.0 & [60] \\
\hline Algeria & 619.0 & 64.0 & 22.0 & [60] \\
\hline China & 356.0 & 318.0 & 1636.0 & [61] \\
\hline Serbia & 200.0 & 77.0 & 1280.0 & [62] \\
\hline Iran & 38.0 & 47.0 & 917.0 & [63] \\
\hline Italy & 81.0 & 129.0 & 1065.0 & [64] \\
\hline Egypt & 65.0 & 60.0 & 920.0 & [65] \\
\hline Saudi Arabia & 89.0 & 105.0 & 773.0 & {$[66]$} \\
\hline
\end{tabular}

\section{Conclusions}

The activity concentrations of primordial radionuclides in rocks from the Precambrian Oban Massif, southeastern Nigeria, were determined from the analysis of rock samples using NAI(Th) gamma ray spectrometric technique. The activity concentration was used 
to map the spatial spread of the radionuclides and infer the radiation-induced challenges that direct and indirect interaction with these rocks may pose to life. Variations in the mean concentrations of the radioelements are $182.22 \pm 0.08$ to $1924.29 \pm 134.63,2.01 \pm 0.38$ to $545.61 \pm 97.46$, and $27.13 \pm 0.20$ to $661.51 \pm 65.78 \mathrm{~Bq} \cdot \mathrm{kg}^{-1}$ for ${ }^{40} \mathrm{~K},{ }^{238} \mathrm{U}$, and ${ }^{232} \mathrm{Th}$, respectively. The spread of the activity concentrations revealed that these primordial radioelements are inhomogeneously distributed, with activity changing spatially with the rock type and location. The distributions of the radiological hazards indicators are as follows: alpha index (0.01-2.73, mean of $\left.0.80 \mathrm{~Bq} \cdot \mathrm{kg}^{-1}\right)$, gamma index $(0.35-4.38$, average of $\left.2.15 \mathrm{~Bq} \cdot \mathrm{kg}^{-1}\right)$, hazard indices-internal $\left(0.31-4.09\right.$, mean of $\left.2.06 \mathrm{~Bq} \cdot \mathrm{kg}^{-1}\right)$, and external (0.25-3.37, mean of $\left.1.63 \mathrm{~Bq} \cdot \mathrm{kg}^{-1}\right)$, representative level index $(0.69-8.76$, mean of $\left.4.30 \mathrm{~Bq} \cdot \mathrm{kg}^{-1}\right)$, radium equivalent $\left(92.52-1246.38\right.$, mean of $\left.602.23 \mathrm{~Bq} \cdot \mathrm{kg}^{-1}\right)$, absorbed dose rate indoors $\left(43.85-544.09\right.$, mean of $\left.270.91 \mathrm{nGy} \cdot \mathrm{h}^{-1}\right)$, outdoors (83.04-1012.24., mean of $\left.509.78 \mathrm{nGy} \cdot \mathrm{h}^{-1}\right)$, annual effective dose equivalent: outdoor $\left(101.81-1241.01 \mathrm{mSv} \cdot \mathrm{yr}^{-1}\right)$, indoor (215.15-2669.33 mSv $\left.\cdot \mathrm{yr}^{-1}\right)$ and total 316.96-3910.34 $\left.\mathrm{mSv} \cdot \mathrm{yr}^{-1}\right)$, cumulative excess lifetime cancer risk (1045.95-12,904.11) and annual gonadal dose equivalent (310.74-3761.47 Bq $\left.\cdot \mathrm{kg}^{-1}\right)$. These results exceeded their various permissible limits in many locations (except at Ako Community), thereby suggesting that rocks in the area may be unsuitable for use in constructing dwelling places. The activity concentrations are highest in biotite garnet schist, quartz diorite, and biotite gneiss rocks. Even though their environmental impacts may not be very severe because other researchers have reported higher values in other parts of the world, utmost care should be taken while dealing with these rocks. However, basic safety standards and precautionary measures recommended by [55] should be strictly adhered to while dealing with these rocks.

Author Contributions: Conceptualization, E.E.E. and A.E.A.; methodology, E.E.E. and S.E.E.; software, U.C.B.; validation, S.E.E., E.D.E. and A.E.A.; formal analysis, A.M.E.; investigation, E.E.E.; resources, U.C.B.; data curation, S.E.E.; writing—original draft preparation, E.E.E.; writing-review and editing, D.G.-O.; visualization, A.E.A. and A.M.E.; supervision, A.E.A.; project administration, K.A.; funding acquisition, K.A. All authors have read and agreed to the published version of the manuscript.

Funding: Researchers Supporting Project (number RSP-2022/351), King Saud University, Riyadh, Saudi Arabia, for funding this research article.

Data Availability Statement: The data that support the findings of this study are available from the corresponding author upon reasonable request.

Acknowledgments: The authors are thankful to the Management and Staff of the National Institute of Radiation Protection and Research, University of Ibadan, Nigeria, for analyzing the rock samples. Sincere thanks and gratitude to the Researchers Supporting Project (number RSP-2022/351), King Saud University, Riyadh, Saudi Arabia, for funding this research article.

Conflicts of Interest: The authors declare no conflict of interest. Competing interests: The corresponding author wishes to state on behalf and after due confirmation from every author associated with this research work that there are no interests existing or of perceptibly potential conflicting with this study.

\section{References}

1. Winterkorn, H.F.; Pamukcu, S. Soil stabilization and grouting. In Foundation Engineering Handbook; Springer: Boston, MA, USA, 1991; pp. 317-378.

2. Akpan, A.E.; Ukwang, E.E.; Esu, E.O. Assessment of the potentials of some engineering materials in parts of Akamkpa, southeastern Nigeria. J. Min. Geol. 2011, 40, 113-119.

3. Egesi, N.; Tse, C.A. Dimension stone: Exploration, evaluation and exploitation in southwest parts of Oban Massif Southeastern Nigeria. J. Geol. Min. Res. 2011, 3, 115-122.

4. Ekwueme, B.N.; Akpeke, G.B.; Ephraim, B.E. The chemical composition and industrial quality of Barite mineralization in Calabar flank, Oban Massif, Mamfe embayment and Obudu Plateau, southeastern Nigeria. Glob. J. Geol. Sci. 2015, 13, 53-66. [CrossRef]

5. Gbenu, S.T.; Oladejo, O.F.; Alayande, O.; Olukotun, S.F.; Fasasi, M.K.; Balogun, F.A. Assessment of radiological hazard of rock aggregates from Southwestern Nigeria. J. Radiat. Res. Appl. Sci. 2016, 9, 20-25. [CrossRef] 
6. Essien, I.E.; Essiett, A.A.; Ani, O.B.; Peter, I.G.; Udofia, A.E. Estimation of Radiological Hazard Indices Due to Radioactivity in Soils in Ibiono Ibom, Akwa Ibom State, Nigeria. Int. J. Sci. Res. Publ. 2017, 7, 245-251.

7. Guagliardi, I.; Zuzolo, D.; Albanese, S.; Lima, A.; Cerino, P.; Pizzolante, A.; Thiombane, M.; De Vivof, B.; Cicchella, D. Uranium, thorium and potassium insights on Campania region (Italy) soils: Sources patterns based on compositional data analysis and fractal model. J. Geochem. Explor. 2020, 212, 106508. [CrossRef]

8. Pulford, I. Gold and Uranium. In Trace Elements in Soils; Hooda, P., Ed.; Wiley: Chichester, UK, 2010; pp. 551-565.

9. Ekwok, S.E.; Akpan, A.E.; Achadu, O.I.M.; Eze, O.E. Structural and lithological interpretation of aero-geophysical data in parts of the Lower Benue Trough and Obudu Plateau, Southeast Nigeria. Adv. Space Res. 2021, 68, 2841-2854. [CrossRef]

10. Akpan, A.E.; Paul, N.D.; Uwah, E.J. Ground radiometric investigation of natural radiation levels and their radiological effects in Akpabuyo, Nigeria. J. Afr. Earth Sci. 2016, 123, 185-192. [CrossRef]

11. Akpan, A.E.; Ebong, E.D.; Ekwok, S.E.; Eyo, J.O. Assessment of radionuclide distribution and associated radiological hazards for soils and beach sediments of Akwa Ibom Coastline, southern Nigeria. Arab. J. Geosci. 2020, 13, 1-12. [CrossRef]

12. Edet, A.E. A preliminary assessment of the concentrations of rare earth elements in an acidic fresh groundwater (southeastern Nigeria). Appl. Earth Sci. 2004, 113, 100-109. [CrossRef]

13. Haase, G.; Vagt, T.; Fritsche, J. Monitoring environmental radionuclide activity of the incident-relevant radionuclides 137Cs und 90Sr in animal feed and foodstuffs consumed in Germany. J. Consum. Prot. Food Saf. 2021, 16, 97-101. [CrossRef]

14. Hanifah, N.A.; Hashim, S.; Hassan, H.J.; Abdul Hadi, M.R.F.; Sanusi, M.S.M.; Bradley, D.A.; Garcia-Tenorio, R.; Tahar, R.M. Radiation hazard assessment from NORM-added paint products in Malaysia. J. King Saud Univ. Sci. 2022, 34, 1850. [CrossRef]

15. Alnour, I.A.; Wagiran, H.; Ibrahim, N.; Laili, Z.; Omar, M.; Hamzah, S.; Idi, B.Y. Natural radioactivity measurements in the granite rock of quarry sites, Johor, Malaysia. Radiat. Phys. Chem. 2012, 81, 1842-1847. [CrossRef]

16. Sanjurjo-Sánchez, J.; Alves, C. Geologic materials and gamma radiation in the built environment. Environ. Chem. Lett. 2017, 15, 561-589. [CrossRef]

17. Caffrey, E.A.; Rood, A.S.; Grogan, H.A.; Till, J.E.; Herman, K. Dose Assessment for Technologically Enhanced Naturally Occurring Radioactive Materials Disposal in Landfills. Health Phys. 2021, 121, 209-224. [CrossRef] [PubMed]

18. Khandaker, M.U.; Jojo, P.J.; Kassim, H.A. Determination of primordial radionuclides in natural samples using HPGe gamma-ray spectrometry. APCBEE Procedia 2012, 1, 187-192. [CrossRef]

19. Prasad, M.; Ranga, V.; Kumar, G.A.; Ramola, R.C. Radiological impact assessment of soil and groundwater of Himalayan regions in Uttarakhand, India. J. Radioanal. Nucl. Chem. 2020, 323, 1269-1282. [CrossRef]

20. Dupree-Ellis, E.; Watkins, J.; Ingle, J.N.; Phillips, J. External radiation exposure and mortality in a cohort of uranium processing workers. Am. J. Epidemiol. 2000, 152, 91-95. [CrossRef]

21. McGeoghegan, D.; Binks, K. The mortality and cancer morbidity experience of workers at the Capenhurst uranium enrichment facility 1946-1995. J. Radiol. Prot. 2000, 20, 381. [CrossRef]

22. Käsmann, L.; Dietrich, A.; Staab-Weijnitz, C.A.; Manapov, F.; Behr, J.; Rimner, A.; Jeremic, B.; Senan, S.; De Ruysscher, D.; Lauber, K.; et al. Radiation-induced lung toxicity-cellular and molecular mechanisms of pathogenesis, management, and literature review. Radiat. Oncol. 2020, 15, 1-16. [CrossRef]

23. Klaus, R.; Niyazi, M.; Lange-Sperandio, B. Radiation-induced kidney toxicity: Molecular and cellular pathogenesis. Radiat. Oncol. 2021, 16, 1-11. [CrossRef] [PubMed]

24. Akpanowo, M.A.; Umaru, I.; Iyakwari, S.; Joshua, E.O.; Yusuf, S.; Ekong, G.B. Determination of natural radioactivity levels and radiological hazards in environmental samples from artisanal mining sites of Anka, North-West Nigeria. Sci. Afr. 2020, 10, e00561. [CrossRef]

25. Khater, A.E.; Higgy, R.H.; Pimb, M. Radiological impacts of natural radioactivity in Abu-Tartur phosphate deposits, Egypt. J. Environ. Radioact. 2001, 55, 255-267. [CrossRef]

26. Asinya, E.A.; Oden, M.I.; Ephraim, B.E.; Udinmwen, E.; Edem, S.U. Mesoscopic structural analysis of the schist enclaves in Oban Massif, Southeastern Nigeria. Asian J. Phys. Chem. Sci. 2016, 1, 1-14.

27. Oden, M.I.; Asinya, A.E.; Udinmwen, E. The schist enclaves of Oban Massif, Southeastern Ngeria: Consistency of dihedral angle and other natural physical and mechanical properties. J. Geogr. Environ. Earth Sci. Int. 2017, 9, 1-13. [CrossRef]

28. Salminen, R.; Plant, J.A.; Reeder, S.; Salminen, R. Geochemical Atlas of Europe. Part 1, Background Information, Methodology and Maps; Geological Survey of Finland: Espoo, Finland, 2005; Volume 525.

29. Reimann, C.; Filzmoser, P.; Garrett, R.G.; Dutter, R. Statistical Data Analysis Explained. Applied Environmental Statistics with R; Wiley: Chichester, UK, 2008; 343p.

30. Alabi, O.O.; Akinluyi, F.O.; Ojo, M.O.; Adebo, B.A. Radiogenic Heat Production of Rocks from Three Rivers in Osun State, Nigeria J. Appl. Sci. 2007, 7, 1661-1663. [CrossRef]

31. Asaduzzaman, K.; Mannan, F.; Khandaker, M.U.; Farook, M.S.; Elkezza, A.; Amin, Y.B.; Sharma, S.; Kassim, H.B. Assessment of natural radioactivity levels and potential radiological risks of common building materials used in Bangladeshi Dwellings. PLoS ONE 2015, 10, e0140667. [CrossRef]

32. Oladejo, O.F.; Olukotun, S.F.; Ogundele, L.T.; Gbenu, S.T.; Fakunle, M.A. Radiological risk assessment of naturally occurring radioactive materials (NORMS) from selected quarry sites in Edo State, South-south, Nigeria. Environ. Earth Sci. 2020, 79, 8842. [CrossRef] 
33. Bochiolo, M.; Verdoya, M.; Chiozzi, P.; Pasquale, V. Radiometric surveying for the assessment of radiation dose and radon specific exhalation in underground environment. J. Appl. Geophys. 2012, 83, 100-106. [CrossRef]

34. Reus, U.; Westmeier, W. Catalog of gamma rays from radioactive decay Part 1. At. Data Nucl. Data Tables 1983, 29, 398. [CrossRef]

35. Ehsan, M.S.; Rahman, M.F.; Tabassum, N.; Prodhan, M.M.H.; Pervin, S.; Siraz, M.M.; Mahal, S.F. The Activity Concentration of Radionuclides (226Ra, 232Th and 40K) in Soil Samples and Associated Health Hazards in Natore, Kushtia and Pabna District of Bangladesh. J. Bangladesh Acad. Sci. 2019, 43, 169-180. [CrossRef]

36. UNSCEAR (United Nations Scientific Committee on the Effects of Atomic Radiation). Sources and Effects of Ionizing Radiation; UNSCEAR: New York, NY, USA, 2000.

37. Beretka, J.; Mathew, P.J. Natural radioactivity of Australian building materials, industrial wastes and by-products. Health Phys. 1985, 48, 87-95. [CrossRef] [PubMed]

38. Tufail, M.; Nasim-Akhtar, S.-J.; Hamid, T. Natural radioactivity hazards of building bricks fabricated from saline soil of two districts of Pakistan. J. Radiol. Prot. 2007, 27, 481-492. [CrossRef] [PubMed]

39. Ademola, A.K.; Belo, A.K.; Adejumobi, A.C. Determination of natural radioactivity and hazard in soil samples in and around gold mining area in Itagunmodi, Southwestern Nigeria. J. Radiat. Res. Appl. Sci. 2014, 7, 249-255. [CrossRef]

40. Isinkaye, M.O.; Emelue, H.U. Natural radioactivity measurements and evaluation of radiological hazards in sediment of Oguta Lake, South East Nigeria. J. Radiat. Res. Appl. Sci. 2015, 8, 459-469. [CrossRef]

41. Taskin, H.; Karavus, M.; Ay, P.; Topuzoglu, A.; Hindiroglum, S.; Karahan, G. Radionuclide concentrations in soil and lifetime cancer risk due to gamma radioactivity in Kirklareli, Turkey. J. Environ. Radioact. 2009, 100, 49-53. [CrossRef]

42. Habib, M.A.; Basuki, T.; Miyashita, S.; Bekelesi, W.; Nakashima, S.; Phoungthong, K.; Khan, R.; Rashid Islam, A.R.M.T.; Techato, K. Distribution of naturally occurring radionuclides in soil around a coal-based power plant and their potential radiological risk assessment. Radiochim. Acta 2019, 107, 243-259. [CrossRef]

43. Underhill, P.T. Naturally Occurring Radioactive Material: Principles and Practices; Routledge: Oxfordshire, UK, 2018.

44. Moghazy, N.M.; El-Tohamy, A.M.; Fawzy, M.M.; Awad, H.A.; Zakaly, H.M.H.; Issa, S.A.M.; Ene, A. Natural Radioactivity, Radiological Hazard and Petrographical Studies on Aswan Granites Used as Building Materials in Egypt. Appl. Sci. 2021, 11, 6471. [CrossRef]

45. Fyfe, W.S. Geochemistry. In Encyclopedia of Geochemistry; Marshall, C.P., Fairbridge, R.W., Eds.; Kluwer Academic Publishers: Dordrecht, The Netherlands, 1999; pp. 277-279.

46. Zhao, W.W.; Zhou, M.F.; Li, Y.H.M.; Zhao, Z.; Gao, J.F. Genetic types, mineralization styles, and geodynamic settings of Mesozoic tungsten deposits in South China. J. Asian Earth Sci. 2017, 137, 109-140. [CrossRef]

47. Galbraith, J.H.; Saunders, D.F. Rock Classification by Characteristics of aerial gamma-ray measurements. J. Geochem. Explor. 1983, 18, 49-73. [CrossRef]

48. Avwiri, G.O.; Ononugbo, C.P.; Nwokeoji, I.E. Radiation hazard indices and excess lifetime cancer risk in soil, sediment and water around mini-okoro/oginigba creek, port Harcourt, rivers state, Nigeria. Compr. J. Environ. Earth Sci. 2014, 3, 38-50.

49. Buccianti, A.; Apollaro, C.; Bloise, A.; De Rosa, R.; Falcone, G.; Scarciglia, F.; Tallarico, A.; Vecchio, G. Natural Radioactivity levels (K, Th, U and Rn) in the Cecita Lake area (Sila Massif, Calabria, southern Italy) an attempt to discover correlations with soil features on a statistical base. Geoderma 2009, 152, 145-156. [CrossRef]

50. International Atomic Energy Agency (IAEA). Internal Basic Safety Standards for Protection against Ionizing Radiation and for the Safety of Radiation Sources; Safety Series No. 115; International Atomic Energy Agency: Vienna, Austria, 1996.

51. Imani, M.; Adelikhah, M.; Shahrokhi, A.; Azimpour, G.; Yadollahi, A.; Kocsis, E.; Toth-Bodrogi, E.; Kovács, T. Natural radioactivity and radiological risks of common building materials used in Semnan Province dwellings, Iran. Environ. Sci. Pollut. Res. 2021, 28, 41492-41503. [CrossRef]

52. Stegnar, P.; Shishkov, I.; Burkitbayev, M.; Tolongutov, B.; Yunusov, M. Assessment of the radiological impact of gamma and radon dose rates at former U mining sites in Central Asia. J. Environ. Radioact. 2013, 123, 3-13. [CrossRef] [PubMed]

53. Al-Jundi, J.; Salah, M.; Bawa'aneh, M.S.; Afaneh, F. Exposure to radiation from the natural radioactivity in Jordanian building materials. Radiat. Prot. Dosim. 2005, 118, 93-96. [CrossRef] [PubMed]

54. Arafa, W. Specific activity and hazards of granite samples collected from the Eastern Desert of Egypt. J. Environ. Radioact. 2004, 75, 315-327. [CrossRef]

55. European Commission. Council Directive 2013/59/Euratom of 5 December 2013 laying down basic safety stanards for protection against the dangers arising from exposure to ionising radiation, and repealing Directives 89/618/Euratom, 90/641/Euratom, 96/29/Euratom, 97/43/Euratom and 2003/122/Euratom. Off. J. Eur. Comm. 2014, 13, 1-73.

56. Ravisankar, R.; Raghu, Y.; Chandrasekaran, A.; Gandhi, M.S.; Vijayagopal, P.; Venkatraman, B. Determination of Natural Radioactivity and the Associated Radiation Hazards in Building Materials used in Polur, Tiruvannamalai District, Tamilnadu, India using Gamma Ray Spectrometry with Statistical Approach. J. Geochem. Explor. 2016, 163, 41-52. [CrossRef]

57. Sam, A.K.; Ahmad, M.M.O.; El Khngi, F.A.; El-Nigumi, Y.O.; Holm, E. Radiological and assessment of Uro and Kurun rock phosphates. J. Environ. Radioact. 1999, 24, 65-75. [CrossRef]

58. Guimond, R.J. Radium in Fertilizers. The Environmental Behaviour of Radium; Technical Report No. 310; International Atomic Energy Agency: Vienna, Austria, 1990; pp. 113-128.

59. Makweba, M.M.; Holm, E. The natural radioactivity of the rock phosphates, phosphatic products and their environmental implications. Sci. Total Environ. 1993, 133, 99-110. [CrossRef] 
60. Olszewska-Wasiolek, M. Estimates of the occupational radiological hazard in phosphate fertilizers industry in Poland. Radiat. Prot. Dosim. 1995, 58, 269-276.

61. Tuo, F.; Peng, X.; Zhou, Q.; Zhang, J. Assessment of natural radioactivity levels and radiological hazards in building materials. Radiat. Prot. Dosim. 2020, 188, 316-321. [CrossRef] [PubMed]

62. Kuzmanović, P.; Todorović, N.; Filipović Petrović, L.; Mrđa, D.; Forkapić, S.; Nikolov, J.; Knežević, J. Radioactivity of building materials in Serbia and assessment of radiological hazard of gamma radiation and radon exhalation. J. Radioanal. Nucl. Chem. 2020, 324, 1077-1087. [CrossRef]

63. Abbasi, A. Calculation of gamma radiation dose rate and radon concentration due to granites used as buildingmaterials in Iran. Radiat. Prot. Dosim. 2013, 155, 335-342. [CrossRef] [PubMed]

64. Righi, S.; Bruzzi, L. Natural radioactivity and radon exhalation inbuilding materials used in Italian dwellings. J. Environ. Radioact. 2006, 88, 158-170. [CrossRef]

65. Medhat, M.E. Assessment of radiation hazards due to natural radioactivity in some building materials used in Egyptian dwellings. Radiat. Prot. Dosim. 2009, 133, 177-185. [CrossRef]

66. Al-Sewaidan, H.A. Natural radioactivity measurements and dose rate assessment of selected ceramic and cement types used in Riyadh, Saudi Arabia. J. King Saud. Univ. Sci. 2019, 31, 987-992. [CrossRef] 